\title{
RED CELL SUBSTITUTES
}

\section{Need for a red cell substitute}

The disadvantages of blood transfusion

- Storage

- Transport

- Short shelf life

- Difficult to obtain

- Needs crossmatching
William Odling-Smee

The ability to transfuse blood successfully has made possible some of the important medical advances this century. It has played a considerable part in lowering maternal mortality during childbirth and in the development of cardiac surgery. It has made most operations so much safer that it is difficult for those of us who qualified after 1945 to envisage surgery without blood transfusion. There are, however, disadvantages, which become apparent at the extremes of use.

Blood has to be stored at $4^{\circ} \mathrm{C}$, which means that it must be kept in a refrigerator. It cannot be stored on a shelf in a pharmacy; transport can therefore be an additional problem. Blood has a short shelf ( 36 days), even when the more advanced storage solutions are used, and this results in much of the blood that has been collected being disposed of unused, although many of the products of whole blood may have been extracted and stored. This is a pity because blood is usually given in this country in the expectation that it will "save a life."

In many parts of the world, however, it is not so freely available. Religious taboos forbid its donation, and in many cultures it is believed that life resides in the blood and if it is given away then some of that person's "life force" is lost, thereby weakening that person.

The other problem of blood transfusion is the need to crossmatch blood. The antigenicity of the blood is carried in the red cell envelope, and there is no evidence that the haemoglobin that is removed from the red cell is antigenic. Despite accurate crossmatching transfusion reactions still occur, probably because of an unidentified antigen.

All these problems would be solved if a fluid were developed that had the same osmolarity as blood and that would pick up oxygen in the lungs and deliver it to the tissues when it was needed. It would need a long shelf life at temperatures up to $40^{\circ} \mathrm{C}$, it would not need to be crossmatched, and it would have no reactions when infused into humans. The surgeon could then measure the oxygen carrying capacity of the blood and when it fell below an arbitrary value of $70 \%$ during operation could give the red cell substitute.

A red cell substitute should be able to pick up oxygen in the lungs and transport and deliver it to the tissues. It should be immunogenically inert. It should be isotonic with blood, so that it does not cause fluid to move into or out of the intravascular compartment and, above all, it should be safe. There are three substances that come near to satisfying these criteria: modified haemoglobin solutions, microencapsulated haemoglobin, and perfluorochemicals.
- Microencapsulated haemoglobin

- Perfluorochemicals 


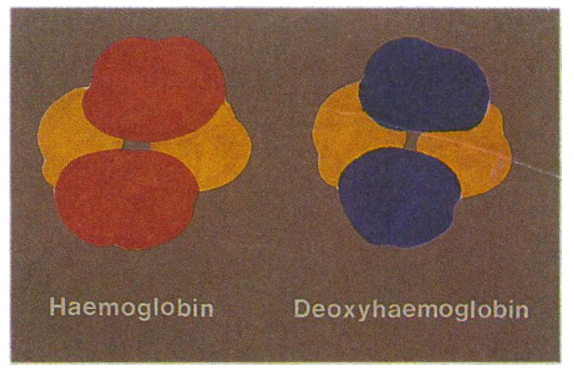

Artist's impression of a haemoglobin molecule.

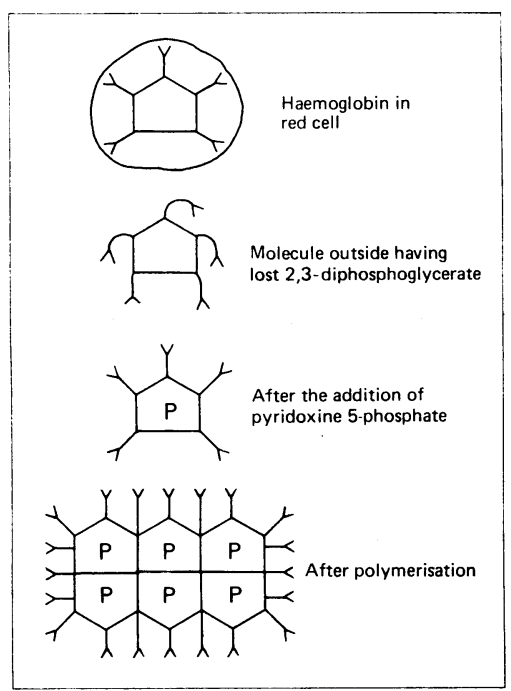

Preparation of haemoglobin solution.

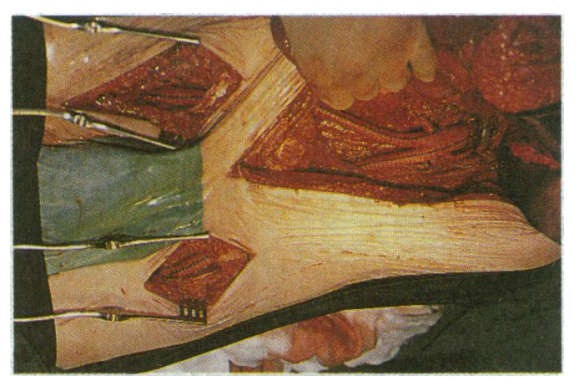

Aortobifemoral graft.

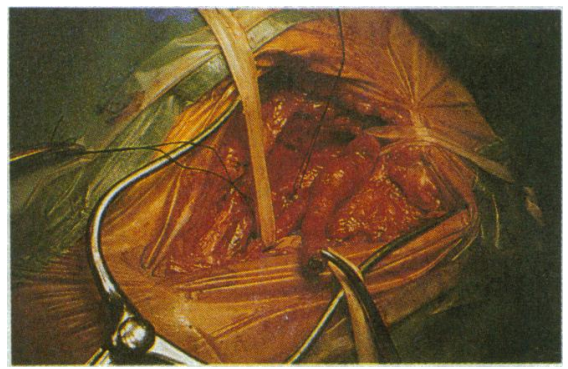

Occluded superficial femoral artery being prepared for arterial patch profundaplasty.
Modified haemoglobin solutions

Haemoglobin will perform its physiological functions outside the red cell. For many years it was believed that haemoglobin was nephrotoxic, but it has recently been shown that it is the red cell stroma and not the haemoglobin itself that is nephrotoxic. When haemoglobin is released from the red cell it loses its ability to hold 2, 3-diphosphoglycerate, which is essential for a low oxygen affinity (the ability to pick up oxygen in the lungs and release it in the tissues). This is usually expressed as $P_{50}$ - the partial pressure of oxygen when the blood is $50 \%$ saturated. The 2, 3-diphosphoglycerate can, however, be replaced by pyridoxine 5-phosphate, which remains within the molecule and brings the oxygen affinity back to that of whole blood.

The other problem with such solutions is that haemoglobin is a small molecule that easily escapes through the glomeruli and is excreted within a short time. This can be overcome by polymerising the molecule, which causes a fourfold increase in its half life in the circulation. The process of polymerisation is viricidal, which is an advantage, and it also lowers the osmolality of the solution, permitting concentrations of up to $150 \mathrm{~g} / \mathrm{l}$ that will therefore carry more oxygen in each litre.

The solution does not block the reticuloendothelial system and does not interfere with neutrophil killing or chemotaxis. It can be prepared so that it is sterile and free of both pyrogen and endotoxin. There is a small molecule substance that is a potent vasoconstrictor and comes from the red cell, but this can be removed by dialysis so the solution therefore seems to be safe.

\section{Microencapsulated haemoglobin}

An alternative to polymerisation of haemoglobin to keep it for longer in the circulation is to incorporate it in a lipid membrane. This prevents the escape of the molecule through the glomeruli, and the oxygen affinity of the solution containing the microspheres is similar to that of whole blood; if pyridoxine 5-phosphate is added to the haemoglobin first a stable product is created. The half life in the circulation is about 20 hours, which is similar to that of a polymerised haemoglobin solution. Oxygen diffuses easily across the membrane, and studies in experimental animals have suggested that this substance can keep animals alive that have had over $90 \%$ of their red cells removed. There is little information about its toxicity.

It is doubtful if microencapsulation has any advantage over polymerisation. There does not seem to be any logic in putting a layer of lipid between the haemoglobin and the tissues. Polymerisation achieves the same effect of lengthening the time that the haemoglobin can be kept in the circulation.

\section{Perfluorochemical emulsions}

Perfluorochemicals are not soluble in water and they dissolve oxygen. When they are prepared as an emulsion they will carry oxygen between the molecules and give it up easily when the oxygen tension is low-for example, in the tissues. The relation between oxygen tension and partial pressure is a straight line, in contrast to the sigmoid curve of whole blood (and haemoglobin). The emulsions can be chemically adjusted so that osmotic and oncotic pressures, $\mathrm{pH}$, and electrolyte concentrations are physiological. Their most serious drawback is that for the emulsions to be fully effective the patient must breathe an oxygen enriched atmosphere. Some of the newer perfluorochemicals are, however, said to have overcome this problem.

As they are small molecules their intravascular persistence is short, but they do persist in the cells of the reticuloendothelial system for a long time. At present the emulsions must be stored at $-20^{\circ} \mathrm{C}$ (which is a disadvantage), and, although immediate toxic effects are recorded, they have been used only in patients who are already seriously ill and nothing is known about long term toxicity.

The one potential advantage of perfluorochemicals is their low viscosity; this might have potential applications in limb salvage procedures for severe atherosclerosis or in patients with myocardial infarction. 
Conclusions

\begin{tabular}{|c|c|c|}
\hline $\begin{array}{l}\text { Substance } \\
\text { needed }\end{array}$ & Cause & Blood product \\
\hline Oxygen & $\begin{array}{l}\text { Anaemia } \\
\text { Haemorrhage }\end{array}$ & $\begin{array}{l}\text { Modified } \\
\text { haemoglobin } \\
\text { solution }\end{array}$ \\
\hline Clotting factors & $\begin{array}{l}\text { Massive } \\
\text { transfusion } \\
\text { Dyscrasias }\end{array}$ & Clotting factors \\
\hline Platelets & $\begin{array}{l}\text { Massive } \\
\text { transfusion } \\
\text { Thrombocytopenia }\end{array}$ & Platelets \\
\hline $\begin{array}{l}\text { Circulatory } \\
\text { expansion }\end{array}$ & $\begin{array}{l}\text { Haemorrhage } \\
\text { Dehydration }\end{array}$ & $\begin{array}{l}\text { Balanced } \\
\text { electrolyte } \\
\text { solutions } \\
\text { Dextrans }\end{array}$ \\
\hline
\end{tabular}

The illustration of the aortobifemoral graft is produced by courtesy of Mr A A B Barros D'Sa, and that of the occluded superficial femoral artery by courtesy of $\mathrm{Mr} \mathrm{A} \mathrm{V}$ Pollock.
Blood comprises a whole series of different products that act against infection, stop haemorrhage after trauma, carry oxygen to the tissues, and take metabolites away from the tissues. Recently efforts have been directed towards supplying the deficiencies in each function separately so that factors are available to supply each individual deficiency.

Similarly, when oxygen is required by the tissues, red cell substitutes should be able to deliver it. When it is the red cells themselves that are missing (as in patients with haemorrhage or anaemia) a modified haemoglobin solution might provide the answer, but when it is difficult to get oxygen into the blood -as in patients with the adult respiratory distress syndrome or those with severe pulmonary embolus-perfluorochemicals infused intraperitoneally might be effective. Both these substances have low $\bar{\Phi}$ viscosity and so permit better perfusion of the microcirculation. Much is now known about the reaction of these substances in animals; more studies in humans are urgently needed.

William Odling-Smee, FRCS, is senior lecturer in surgery, Queen's University of Belfast.

\section{BOOKS RECEIVED}

\section{Alternative medicine}

Garlic: the Life-Blood of Good Health $S$ Fulder. (Pp 96; $\{2.99$ paperback.) Wellingborough: Thorsons, 1989 ISBN 0-7225-2132-4.

Loving Medicine: Patients' Experiences of the Bristol Cancer Help Centre. R Thomson. (Pp 219; 55.95 paperback.) Bath: Gateway Books, 1989. ISBN 0 946551-49-9.

Oh for Another Osteopath! B Bloomfield. (Pp iv +60; figs; £2 paperback + postage and packing 35p.) Obtainabte from Information and Study Centre for Alternative Medicine, 64 Bower Mount Road, Maidstone, Kent ME16 8AT.

The Omega-3 Phenomenon: the Nutrition Breakthrough of the '80s. D Rudin, C Felix, with C Schrader. (Pp xvii +286 E7,99 paperback.) London: Sidgwick and Jackson, 1989. ISBN Q-283 99719-2.

Royal felly: the New Guide to Nature's Richest Health Food. I Stein. (Pp
128; figs; $£ 3.99$ paperback.) Welling128; figs; $£ 3.99$ paperback.) Welling 7225-2159-6.

\section{Anaesthesia}

Anaesthesia and Intensive Care: Practical Procedures. N Soni. (Pp viii +225 ; figs; $\{27.50$ paperback.) London: Heinemann, 1989. ISBN 0-43300062-7.

Anaesthesia Databook: a Clinical Practice Compendium. R A Mason. (Pp Cuint 29 , 224.95.) Edinburg 443-04120-2.

Anaesthesia for Uncommon Diseases. B J Pollard, M J Harrison. (Pp viii +271 $£ 16.50$ paperback.) Oxford: Blackwell Scientific, 1989. ISBN 0-632-02406-2. Anaesthesia: Review 6. Ed L Kaufman. (Pp x+330; figs; £17.95 paperback.) Edinburgh: Churchill Livingstone, 1989. ISBN 0-443-04024-9.

Anatomy

A Colour Atlas of the Skull. B K B Berkovitz, B J Moxham. (Pp 112; figs; colour plates; £25.) London: Wolfe colour plates; £25.) London: Wolf

Histology

Recent Advances in Histopathology. No. 14. Ed P P Anthony, R N M Macsween. (Pp x+308; figs; £22.50 paperback. Edinburgh: Churchill Livingstone, 1989. ISBN 0-443-03998-4.

\section{History of medicine}

A Bibliography of Medical and Biomedical Biography. L T Morton, R J
Moore. (Pp ix +208; £37.50.) Aldershot: Scolar Press, 1989. ISBN 085967-797-4.

Mutual Friends: Charles Dickens and Great Ormond Street Children's Hospital. J Kosky. (Pp x+245; figs; £14.95.) London: Weidenfeld and John O'Connell: Man of Barts. P Upton. (Pp v +129; figs; $£ 5+77 \mathrm{p}$ for packing and postage, paperback.) packing and postage, paperback.)
Published privately, 1989. Available from P K Upton, 3 Back Street, St from P K Upton, 3 Back Street, St
Cross, Winchester, Hants SO23 9SB.

\section{Immunology}

Contributions to Microbiology and Immunology. Vol 11. "B Lymphocytes: Function and Regulation." Ed P del Guercio, J M Cruse. Series editors J M Cruse, R E Lewis Jr. (Pp vi + 310; figs; £115.90.) Basel: Karger, 1989. Distributed by John Wiley and Sons. ISBN 3-8055-4995-4.

An Introduction to Clinical Immunology. F K Widmann. (Pp xvii +424; figs: £18.33 paperback.) Philadelphia: Davis, 1989. ISBN 0-8036-9311-7.

Soviet Medical Reviews Supplement Series. "Immunology Volume 1: Petrov, R M Khaitov, B V Pinegin. Translated from the Russian by V E Tatarchenko. (Pp xi+ 208; figs; \$155.) Chur, Switzerland: Harwood Academic Publishers, 1989. ISBN 3-7186mic Pub-8.

\section{Neurology}

The Cerebrospinal Fluid. Ed R M Herndon, R A Brumback. (Pp xiv+ 306; figs; colour plates; $\$ 78.25$.) Boston: Kluwer Academic, 1989. Distributed

The Experience of Illness. "Epilepsy." G Scambler. Series editors R Fitz patrick, $S$ Newman. ( $P p x+134$; figs \&8.95 paperback.) London: Tavistock Routledge, 1989. ISBN 0-415-017580 .

Medical Neurology. D Chadwick, N Cartlidge, D Bates. (Pp vii + 506; figs; Cartlidge, D Bates. (Pp vii + 506; figs;
\{24.95 paperback.) Edinburgh: \{24.95 paperback.) Edinburgh:
Churchill Livingstone, 1989. ISBN 0Churchill Living

Neuromethods. Vol 11. "Carbohydrates and Energy Metabolism." Ed A A Boulton, G B Baker, R F Butterworth. (Pp xx+383; figs; price not stated.) New Jersey: Huma 1989. ISBN 0-89603-143-8.

\section{Nuclear medicine}

Practical Nuclear Medicine. Ed P F Sharp, H G Gemmell, F W Smith.
(Pp xiv + 349; figs; £40.) Oxford: IRL Press, 1989. ISBN 0-19-963032-1.

\section{Nursing}

Nurse's Manual of Laboratory Tests. J H Cella, J Watson. (Pp xix + 524; figs; £13.89 paperback.) Philadelphia Davis, 1989. ISBN 0-8036-1696-1.

Nutrition

Nutritional Aspects of Essential Hypertension. R B Singh, S S Rastogi. ( $P$ p viii $+226 ; \quad \$ 40$ paperback.) India: Medical Clinics and Hospital Moradabad, 1989. Available from Dr Sushav Singh, Director AdministraSushav Singh, Director Administra-
tion, Medical Hospital and Research tion, Medical Hospital and Research
Centre, Civil Lines, Moradabad 10, Centre,

Rapid Assessment of Community Nutrition Problems: a Case Study of Parbhani India. P Kashyap, $\mathbf{R} \mathbf{H}$ Young. $(\mathbf{P p}$ viii +59 ; figs; price not stated, paperback.) Canada: International Development Research Centre, 1989. ISBN 088936-551-2.

Responsibility for Nutrition Diagnosis: a Report by the Nutrition Working Party of the Social Issues Committee of the Royal Australasian College of Physicians. M Gracey, B Hetzel, R Smallwood, et al. (Pp 61; figs; 110 paperback.) London: Smith-Gordon Nishimura, 1989. ISBN 1-85463-014 8.

Obstetrics and gynaecology

Effective Care in Pregnancy and Childbirth. Two volume set: Vol 1 .

"Pregnancy," vol 2. "Childbirth." Ed I Chalmers, $M$ Enkin, $M$ J N C Keirse. (Pp xxxiii + 1516; figs; £225 the set.) Oxford: Oxford University Press, 1989. ISBN Vol. 1: 0-19-261558-0, 1989. ISBN Vol. 1:

Hysterectomy-the Positive Recovery Plan. A Dickson, N Henriques. ( $P$ 144; figs; $£ 4.99$ paperback.) Wellingborough: Grapevine, 1989. ISBN 0 7225-2162-6.

Obstetrics. Ed Sir A Turnbull, G Chamberlain. (Pp xiii+1200; figs; f95.) Edinburgh: Churchill Livingstone, 1989. ISBN 0-443-03539-3.

Progress in Reproductive Biology and Medicine. Vol 13. "Update on Hormonal Treatment in the Menopause." Volume and series editor $M$ L'Hermite. (Pp viii+108; figs; £40.90.) Basel: Karger, 1989. Distributed by John Wiley and Sons. ISBN 3-8055-4904-0.

\section{Occupational medicine}

CCINFOdisc. A compilation of occupational health and safety infor- mation on Compact Disc Read-Only Memory (CD-ROM) 3 separate discs are available at $\$ 134$ each, overseas. Available from the Canadian Centre for Occupational Health and Safety, 250 Main Street, East Hamilton, Ontario L8N 1H6, Canada.

\section{Oncology}

Cancer Treatment and Research. "Basic and Clinical Concepts of Lun Cancer." Ed H H Hansen. Series editor W L McGuire. (Pp xiii +368; figs; £79.75.) Boston: Kluwe Academic, 1989. Distributed by MTP Press. ISBN 0-7923-0153-6.

Childhood Cancer: Understanding and Coping. H Ekert. (Pp xvii+185; figs; $\$ 16$ paperback.) New York: Gordon and Breach, 1989. ISBN 2-88124-3568.

Clinical Oncology. G J G Rees. (Pp x + 356; 19.95 paperback.) Tunbridg Wells: Castle House, 1989. ISBN 0-7194-0133-X.

Contributions to Oncology. Vol 34 "The Chemotherapy of Malignan Diseases: Research Perspectives." Sedlacek, D Hoffmann, G Schulz, al. Series editors S Eckhardt, J H Holzner, G A Nagel. (Pp ix + 154; figs; \&41.70.) Basel: Karger, 1989. Distri buted by John Wiley and Sons. ISBN 3-8055-4965-2.

Immunology Series. Vol 48. "Adoptive Cellular Immunotherapy of Cancer." Ed H C Stevenson. Editor-in-Chief N $R$ Rose. (Pp xi+242; figs; $\$ 107.50$.) New York: Dekker, 1989. ISBN 08247-8111-2.

\section{Ophthalmology}

Aids to Ophthalmology. P T Khaw, D S Hughes, S J Keightley, et al. (Pp vii + 294; 28.95 paperback.) Edinburgh: Churchill Livingstone, 1989. ISBN 0443-04012-5.

Developments in Ophthalmology. Vol 16. "Proliferative Vitreoretinopathy: Genetics of Glaucoma." Volume and Genetics of Glaucoma." Volume and
series editor W Straub. (Pp viii+118; figs; £51.90.) Basel: Karger, 1989. figs; £51.90.) Basel: Karger, 1989. Distributed by John

Developments in Ophthalmology. Vol 19. "Ultrastructure of the Conjunctival Epithelium." K-P Steuhl. Series editor W Straub. (Pp $x+104$; figs; 140 .) Basel: Karger, 1989. Distributed by John Wiley and Sons. ISBN 3-8055. 4943-1.

\section{Paediatrics}

Handbook of Pediatric Emergencies. Ed G A Baldwin. (Pp xvii +56I; figs; f19.95 paperback.) Boston: Little,

Brown, 1989. Distributed by Churchill ivingstone. ISBN 0-316-07919-7. Pediatric Neuropsychology. G W Hynd, 을 W G Willis. (Pp xxi+355; figs; 227.50 .) $\omega$ Florida: Grune and Stratton, 1988. Distributed by Harcourt Brace Jovan- 